\title{
LEÃo, Ângela Vaz. Henriqueta Lisboa: o mistério da poética. Belo Horizonte: Editora PUCMINAS, 2004.
}

Simara Aparecida Ribeiro Januário Universidade Federal de Minas Gerais

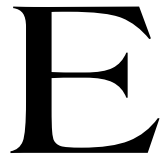

m Henriqueta Lisboa: o mistério da criação poética, Ângela Vaz Leão, que dispensa apresentações, reúne em livro seis ensaios sobre Henriqueta Lisboa originalmente escritos para publicação em jornais e revistas ou para comunicaçóes em eventos que a homenagearam. Nesses textos se vê confirmada a posição da autora como uma leitora atenta e sensível das obras da poeta mineira.

O primeiro ensaio é "Relato de uma experiência pedagógica”, no qual se tem uma espécie de introdução ao livro, além de revelar ao leitor como Ângela Vaz Leão se iniciou na poesia de Henriqueta Lisboa. Esse processo começou em um curso sobre poetas brasileiros (especialmente os mineiros), ministrado no Colégio Izabela Hendrix em 1947, no qual a autora e suas alunas realizavam uma leitura comentada dos poemas de Henriqueta.

Em "Henriqueta Lisboa: evolução de um poeta", Ângela Vaz Leão traça um panorama da obra da poeta, de 1929 a 1963, onde pontua a evolução e o gradativo aumento na qualidade de seus poemas. A Henriqueta tradutora é revelada ao leitor no terceiro ensaio, "Henriqueta Lisboa: leitora e tradutora de Dante", no qual a ensaísta, enfocando a tradução do Canto IX do Purgatório d'A Divina Comédia, de Dante 
Alighieri, destaca a leitura sensível de Henriqueta "deslumbrada diante de tão grave e serena poesia" e o processo de tradução utilizado, pautado por trazer ao texto traduzido "as cores" do original.

O quarto ensaio, "Henriqueta Lisboa: a poesia transcodificada", trata da tradução para o latim do livro de Henriqueta Montanha viva - Caraça, feita por Pedro Sarneel e José Lourenço de Oliveira. Aqui, o leitor passa da poeta tradutora para a poeta traduzida e Ângela Vaz Leão realiza o que Melânia Silva Aguiar (autora do prefácio) chamou de "belo exercício de erudição e sensibilidade", onde se percebe um rico referencial teórico na análise do texto traduzido, bem como o destaque da qualidade e habilidade dos tradutores.

Em "Henriqueta de Minas, Minas de Henriqueta", a autora fala da ligação da poeta com Minas Gerais, nos livros Madrinha Lua (1952), Montanha viva - Caraça (1959) e Belo Horizonte bem-querer (1972), onde se destacam a mineiridade como estado de espírito e os livros dedicados a Minas como monumentos erguidos em defesa da preservação desse sentimento.
Dessa forma, para Ângela Vaz Leão Belo Horizonte bem-querer é um poema de fundo histórico escrito como uma homenagem da autora para agradecer o recebimento do título de cidadã honorária da cidade. Já em Madrinha Lua e Montanha viva - Caraça a poeta estende sua homenagem a toda Minas Gerais: suas paisagens, sua história, sua arte e seus habitantes.

$\mathrm{O}$ último ensaio, "A presença da morte em Henriqueta Lisboa", é uma belíssima reordenação cronológica de poemas de Henriqueta, feita com base em critérios pessoais da ensaísta, que reconta uma possível história de amor vivida pela autora de $A$ face lívida e contada através da presença da morte nos textos selecionados.

Ângela Vaz Leão ressalta que essa história de amor foi "talvez apenas lida pela minha imaginação, talvez criada pela sensibilidade invulgar de Henriqueta, ou talvez vivida realmente por ela própria, mas sublimada através da palavra poética. Como saber?”

A leitura de Henriqueta Lisboa: o mistério da criação poética constitui importante auxílio para os estudiosos e admiradores de 
Henriqueta, sendo meio de aproxi- com a sensibilidade e a sabedoria mação com alguns dos mistérios de sempre presentes na escrita de criação de suas poesias, além de Ângela Vaz Leão.

proporcionar o prazer do contato 